\title{
The impact of revitalization treatments on biological activity of soil under afforestation on post-agricultural land ${ }^{*}$
}

\author{
Wpływ zabiegów zoo- i fitomelioracyjnych na aktywność biologiczną gleby \\ pod zalesieniami na gruntach porolnych
}

\author{
Anna Augustyniuk-Kram ${ }^{1}$, Karol J. Kram ${ }^{2}$ \\ ${ }^{1}$ Institute of Ecology and Bioethics, Cardinal Stefan Wyszyński University in Warsaw, Poland \\ ${ }^{2}$ Kampinos National Park, Poland \\ ORCID AA-K: https://orcid.org/0000-0002-1904-9766•a.kram@uksw.edu.pl
}

\begin{abstract}
In Poland, afforestation is usually carried out on the weakest soils, excluded from agricultural use and wasteland, i.e. post-agricultural land. A characteristic feature of such habitat is poor-quality soil, relatively high content of nutrients for trees, particularly nitrogen, as well as a low level of humus. This is important for the quality of microbiological processes occurring in post-agricultural soils. Restitution of the forest in such a habitat requires the use of various revitalisation treatments for improving soil quality and increasing biological activity and soil fertility. This article presents the results of a long-term experiment on the effectiveness of various revitalisation treatments (z00- and phytomelioration) on afforested post-agricultural lands after more than 30 years from their application in pine forests in north-western Poland. These treatments consisted of introducing additional organic matter into the soil in the form of bark and sawdust, sowing lupine and introducing soil fauna. The comparative area for afforestation on post-agricultural soils in the presented experiment was the area of forest soils, located in the same habitat, in a pine stand, at the same time. Biological activity of soil was measured with the activity of soil enzymes dehydrogenases and acid phosphatase, the biomass of microorganisms was measured and the content of total dissolved carbon and nitrogen was also determined.
\end{abstract}

Keywords: afforestation, post-agricultural land, soil activity, zoo- and phytomelioration

Streszczenie: W Polsce zalesienia zwykle prowadzi się na najsłabszych glebach, wyłączonych z użytkowania rolniczego i nieużytkach czyli tzw. gruntach porolnych. Cechą charakterystyczną takiego siedliska jest słabej jakości gleba, dosyć wysoka zawartość składników pokarmowych dla drzew, w szczególności azotu, a także niewielki poziom próchniczy. Ma to znaczenie dla jakości zachodzących w glebach porolnych procesów mikrobiologizznych. Restytucja lasu na takim siedlisku wymaga stosowania różnych zabiegów rekultywacyjnych polepszających warunki glebowe, zwiększających aktywność biologiczną i żyzność gleby. Wartykule przedstawiono wyniki długoterminowego eksperymentu dotyczącego skuteczności różnych zabiegów zoo- i fitomelioracyjnych na zalesianych gruntach porolnym po ponad 30 latach od ich zastosowania w borach sosnowych w pótnocno-zachodniej Polsce. Zabiegi te polegały na wprowadzeniu do gleby dodatkowej materii organicznej w postaci kory i trocin, wysiano łubin oraz introdukowano faunę glebową. Powierzchnią porównawczą dla zalesień na glebach porolnych w przedstawionym eksperymencie była powierzchnia na glebach leśnych, zlokalizowana na takim samym siedlisku, w drzewostanie sosnowym, w tym samym wieku. Aktywność biologiczną gleby mierzono aktywnością enzymów glebowych-dehydrogenaz i kwaśnej fosfatazy, określono biomasę mikroorganizmów, a także zawartość całkowitego rozpuszczonego węgla i azotu.

Słowa kluczowe: zalesienia, grunty porolne, aktywność gleby, zoo- i fitomelioracja

\footnotetext{
"This article was originally published in Polish as Augustyniuk-Kram, Anna, i Karol J. Kram. 2018. "Wpływ zabiegów zoo- i fitomelioracyjnych na aktywność biologiczną gleby pod zalesieniami na gruntach porolnych." Studia Ecologiae et Bioethicae 16(4): 25-34. The translation of the article into English was financed by the Ministry of Science and Higher Education of the Republic of Poland as part of the activities promoting science - Decision No. 676/P-DUN/2019 of 2 April 2019. Translation made by GROY Translations.
} 


\section{Introduction}

The afforestation of agricultural land and wasteland is one of the main activities and methods of increasing the afforestation rate of our country within the framework of the National Programme for the Augmentation of Forest Cover (Kaliszewski et al. 2014). The period of the most intensive afforestation of post-agricultural land, also including natural succession of forest stands, was in the years 1946-1970, when the area of 37 thousand ha per year, on average, was afforested. In the following years, afforestation was conducted on a lower scale and remained at the level from 12 thousand ha in the years 19711990 to nearly 17 thousand ha per year in the years 1991-2003. From 2004 to 2013, the average area of afforestation amounted to 9.0 thousand ha per year (Kaliszewski et al. 2014). This has led to increasing afforestation rate in our country from $20.8 \%$ in 1945 to $29.5 \%$ in 2016 (Zajączkowski et al. 2017).

Restitution of forest in post-agricultural land is a difficult process due to its specific habitat and soil conditions resulting from many years of agricultural use of soil (Gorzelak 1996; Sobczak 1996; Krawczyk 2014). A characteristic feature of such habitat is poor-quality soil, and a thick plough layer (plough pan) formed as a result of many years of ploughing, making water infiltration and root penetration into the soil profile difficult (Szujecki 1990). Moreover, in post-agricultural soils, in the first years of forest plantation, there is a quite high content of nutrients in particular of nitrogen, when compared with forest soils. Post-agricultural soils are less acidic that typical forest soils. This is of significance for the quality of the microbiological processes occurring in post-agricultural soils. In post-agricultural soils, the level of humus is usually insignificant, and the rate of organic matter (mainly cellulose) decomposition in a post-agricultural soil is based on the activity of bacteria, while in typical forest soils it is based on the active participation of lignin-degrading fungi (Rykowski 1990; Tuszyński 1990).
Our current state of knowledge concerning forest stands on post-agricultural land, their health and condition, and the models and strategies of afforestation that should be used depending on the habitat, results from thorough research and long-term experiments conducted by foresters and scientists (Sobczak 1990; Oszako and Olejarski 2003; Sierota, Błaszczyk, and Zachara 2011). The results presented in this paper were obtained in the course of a longterm experiment set up and coordinated by the Department of Forest Protection and Ecology at Warsaw University of Life Sciences in Warsaw which pertained to the assessment of the effectiveness of selected zoo- and phytomelioration treatments after 30 years from their application in pine forests on post-agricultural lands (Tracz et al. 2014).

\section{Materials and methods 1.1. Description of the experiment and research area}

The experimental area (PE) was set up in autumn 1976 in 79 m forest unit (currently 104Ag and 80c) Niedźwiady forest district (Kamionka forest ranger area) in the Pomorskie Voivodeship on an agricultural wasteland with the area of 1.44 ha $(120 \times 120 \mathrm{~m})$ (Tracz et al. 2014). This area was divided into 6 strips $(120 \times 20 \mathrm{~m})$ and ploughed. On the first, third, and fifth strip, deep ploughing was applied to the depth of up to $40 \mathrm{~cm}$, and on the second, fourth, and sixth strip, shallow ploughing was applied, to the depth of up to $20 \mathrm{~cm}$. In the spring of 1977, each of the strips was divided transversely into three parts $(\mathrm{A}, \mathrm{B}, \mathrm{C}), 800 \mathrm{~m}^{2}$ each, and a variety of zoo- and phytomelioration treatments were applied. The $\mathrm{C}$ plots were covered with pine bark and sawdust, $48 \mathrm{~m}^{3}$ of bark and $24 \mathrm{~m}^{3}$ of sawdust, and ploughed every $1.5 \mathrm{~m}$ perpendicularly to the direction of full ploughing and a one-year-old pine was planted every 1 $\mathrm{m}$. Plots A and B were ploughed in a similar way, except that, after afforestation, garden lupin was sawn into the interrows in plots A, and plots B were left as control plots (Fig. 1). The experiment "was continued" in this configuration until the spring of 1981, when 
to the plots, except for A3, B3, C3, A4, B4 and C4, millipede Proteroiulus fuscus was introduced (750 specimens per each plot) - a detritivore participating in the decomposition of bark and in humification processes (Tracz 1984).

Additionally, an external control area (ZPK) on forest land was selected for the research. The ZPK was located in the same habitat and in a pine forest stand of the same age as the one in the experimental area (PE) (Tracz et al. 2014).

\subsection{Physico-chemical and biological analyses of soil}

Soil samples from the research area were collected three times: on 26 April, 7 July and 27 October 2012. The samples were collected with the use of a soil core sampler (with a diameter of $5 \mathrm{~cm}$ ) from the depth of $10 \mathrm{~cm}$. On each occasion, five soil samples were collected from each of the 18 plots on the experimental area (PE), and five samples from each of the three stands called the external control area (ZPK) (Fig. 1). There were a total of 105 soil samples collected on each date, and each sample was analysed separately.

Directly after the samples were brought to the laboratory, total dissolved carbon (TDC) concentration and total dissolved nitrogen (TDN) concentration, dehydrogenase activity (Dha), acid phosphatase activity (APh) and substrate induced respiration (SIR) were measured. Total dissolved carbon (TDC) and total dissolved nitrogen (TDN) content measurements were carried out in water extracts. Soil samples were weighed, shaken in $300 \mathrm{ml}$ of distilled water for $1 \mathrm{~h}$, and then filtered through a nylon filter. Before the analysis, the samples were additionally filtered through a Teflon filter with $0.45 \mu \mathrm{m}$ pores. Total dissolved carbon and total dissolved nitrogen content was determined with the use of a FormacsHT TOC/TN Analyser (SKALAR Analytical, the Netherlands) and expressed in $\mathrm{mg}$ per $\mathrm{kg}$ of the dry mass of soil.

The dehydrogenase activity was determined in samples of soil of natural moisture, using the procedure by Casida
(Casida, Klein, and Santoro 1964). Triphenyltetrazolium chloride (TTC) which is converted to triphenylformazan (TPF), was used as a substrate. The samples were incubated at a temperature of $30^{\circ} \mathrm{C}$ for 20 hours. The absorbance of TPF $(\mu \mathrm{g} / \mathrm{ml})$ was measured at $485 \mathrm{~nm}$ against ethanol using a spectrophotometer. The dehydrogenase activity of the tested samples was expressed in $\mu \mathrm{g}$ TPF/g of the dry mass of soil. The activity of acid phosphatase was analysed according to the method of Tabatabai and Bremner (Tabatabai and Bremner 1969). A solution of sodium p-nitrophenyl phosphate (PNP) in a universal buffer $(\mathrm{pH}$ $=6.5$ ) was used as the substrate.

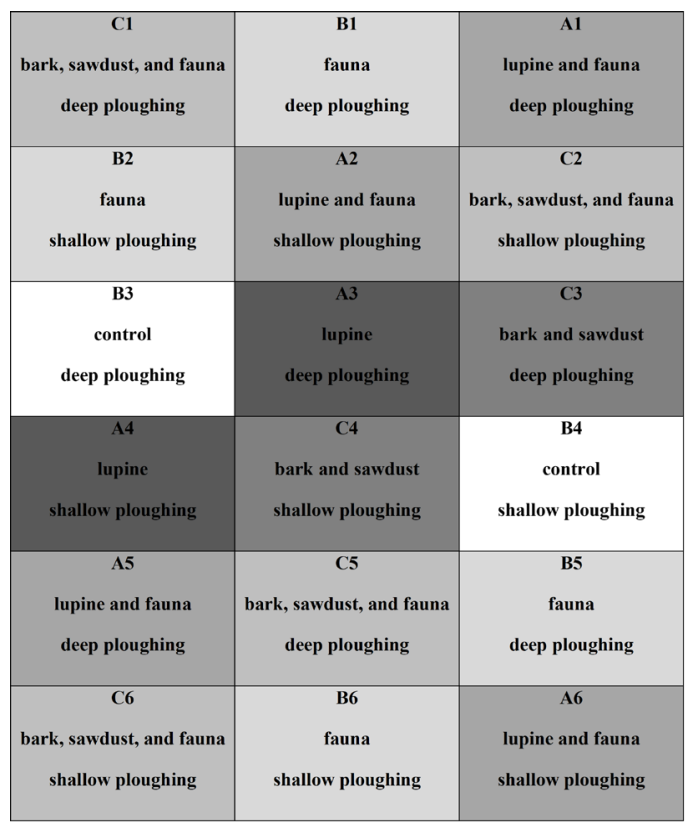

Fig. 1. The layout of the plots in the experimental area with a description of experiment variants (according to Tracz et al. 2014).

The samples were incubated at a temperature of $37^{\circ} \mathrm{C}$ for $1 \mathrm{~h}$. The absorbance of released p-nitrophenol $(\mu \mathrm{g} / \mathrm{ml})$ was measured colorimetrically at $485 \mathrm{~nm}$. The activity of acid phosphatase in soil samples was expressed in $\mathrm{mg}$ of $\mathrm{p}$-nitrophenol/g of dry mass of soil/h. Microbial biomass (micC) was determined by the Substrate Induced Respiration method (Anderson and Domsch 1978). Glucose (30 mg/g of soil) 
in an amount causing maximal initial respiratory response was used as a substrate. The samples were incubated at a temperature of $22^{\circ} \mathrm{C}$. The amount of the released $\mathrm{CO}_{2}$ was measured with an IRGA system (Infra-Red Gas Analyzer) every hour for 5 hours. Microbial biomass was expressed as the amount of carbon $(\mathrm{C})$ of microbial origin $(\mathrm{mic} C)$ in mg per g of dry soil.

\subsection{Statistical analysis of the results}

Arithmetic average and their standard deviations were calculated. The effects of ploughing (shallow ploughing, deep ploughing), treatment (fauna; bark and sawdust; bark, sawdust, and fauna; lupine; lupine and fauna) and the season (spring, summer, autumn) were tested.

For each analysed factor, a one-way analysis of variance (ANOVA) was performed. The significance of differences for individual variables was analysed using the Tukey's HSD test with $\mathrm{p}<0.05$. Differences in the analysed parameters between the experimental area and the external control area in different seasons were tested using the Mann-Whitney U test. The correlation coefficient for the following parameters was also calculated: dehydrogenases activity, acid phosphatase activity, microbial biomass, and total dissolved carbon and nitrogen content. The statistical analysis was performed using the IBM SPSS Statistics package.

\section{Results}

After more than 30 years, the type of ploughing used (shallow and deep) before afforestation of post-agricultural soil on the experimental area did not affect the soil parameters. Parameters such as acid phosphatase activities and biomass of microorganisms on the experimental area were at a similar level to the ones on the external control area. However, it was found that the concentration of total dissolved carbon and total dissolved nitrogen was more than twice as high in the soil of the external control area compared to the plowed soil of the experimental area. On the other hand, dehydrogenase activity was lower in the soil of the external control area compared to the ploughed experimental area (Table 1).

Out of the five land development treatments applied to the experimental area, the best effect was achieved in the bark-sawdust-fauna variant. For this variant, a significantly higher concentration of total dissolved carbon and total dissolved nitrogen, as well as a significantly higher activity of acid phosphatase was found when compared to the control variant, where the soil was not enriched before afforestation with additional organic matter, and no additional fauna was introduced. The applied treatments did not affect dehydrogenases activity and biomass of microorganisms (Table 2). Despite applying treatment to the experimental area, the concentration of total dissolved carbon was 1.5 times higher in the soil of the external control area using the most beneficial variant bark-sawdust-fauna and 3.5 times higher in lupine and lupine-fauna variants (Table 2). In the bark-sawdust-fauna variant, the concentration of total dissolved nitrogen was at the same level as in the soil of the external control area, whereas in other variants of the experiment, the concentra-

Table 1. Soil properties depending on used ploughing before afforestation on the experimental area (PE) compared with the external control area (ZPK) (the table shows average values \pm standard deviation; values in individual columns of PE variants, marked with the same letter, do not differ significantly at $\mathbf{p}<0.05$ ).

\begin{tabular}{lccccc}
\hline PE variants & \multirow{2}{*}{ TDC } & TDN & Dha & APh & micC \\
\hline Shallow ploughing & $71.40 \pm 32.97 \mathrm{a}$ & $2.73 \pm 1.98 \mathrm{a}$ & $10.85 \pm 5.90 \mathrm{a}$ & $2932.0 \pm 060.3 \mathrm{a}$ & $0.63 \pm 0.09 \mathrm{a}$ \\
Deep ploughing & $67.92 \pm 34.80 \mathrm{a}$ & $2.70 \pm 0.22 \mathrm{a}$ & $7.52 \pm 4.05 \mathrm{a}$ & $2337.1 \pm 348.2 \mathrm{a}$ & $0.62 \pm 0.09 \mathrm{a}$ \\
\hline ZPK & $175.02 \pm 125.49$ & $5.46 \pm 7.08$ & $5.47 \pm 2.56$ & $2670.8 \pm 1257.4$ & $0.63 \pm 0.083$ \\
\hline
\end{tabular}


Table 2. Soil properties depending on the treatment applied before afforestation on the experimental area (PE) compared with the external control area (ZPK) (the table shows average values \pm standard deviation; the values in individual columns of PE variants, marked with the same letter, do not differ significantly at $\mathbf{p}<0.05$ ).

\begin{tabular}{lccccc}
\hline PE variants & TDC & TDN & Dha & APh & micC \\
\hline Control & $64.47 \pm 27.69 \mathrm{a}$ & $1.44 \pm 1.92 \mathrm{a}$ & $6.13 \pm 3.30 \mathrm{a}$ & $1800.8 \pm 587.3 \mathrm{a}$ & $0.59 \pm 0.05 \mathrm{a}$ \\
$\begin{array}{l}\text { Fauna } \\
\begin{array}{l}\text { Bark } \\
\text { and sawdust }\end{array}\end{array}$ & $71.47 \pm 30.30 \mathrm{a}$ & $2.67 \pm 2.04 \mathrm{a}$ & $7.52 \pm 5.46 \mathrm{a}$ & $1906.4 \pm 529.5 \mathrm{a}$ & $0.62 \pm 0.09 \mathrm{a}$ \\
$\begin{array}{l}\text { Bark, sawdust, } \\
\text { and fauna }\end{array}$ & $116.37 \pm 32.4 \mathrm{~b}$ & $5.52 \pm 1.92 \mathrm{~b}$ & $12.72 \pm 4.93 \mathrm{a}$ & $3891.4 \pm 1294.2 \mathrm{~b}$ & $0.62 \pm 0.08 \mathrm{a}$ \\
$\begin{array}{l}\text { Lupine } \\
\begin{array}{l}\text { Lupine } \\
\text { and fauna }\end{array}\end{array}$ & $52.83 \pm 20.76 \mathrm{a}$ & $2.82 \pm 0.39 \mathrm{a}$ & $9.52 \pm 4.23 \mathrm{a}$ & $2964.8 \pm 1082.5 \mathrm{a}$ & $0.61 \pm 0.06 \mathrm{a}$ \\
\hline ZPK & $175.02 \pm 125.49$ & $5.46 \pm 7.08$ & $5.47 \pm 2.56$ & $2670.7 \pm 1257.4$ & $0.63 \pm 0.083$ \\
\hline
\end{tabular}

tion of total dissolved nitrogen was 2 to 6 times lower than in the soil of the external control area (Table 2). The acid phosphatase activity in the soil of the external control area was only slightly lower than in the soil of the bark-sawdust-fauna variant and at a similar level to other fertilization variants (Table 2).

The season influenced the examined soil parameters and this influence differed depending on the research area. Concentration of the total dissolved carbon (TDC) in the soil samples from the external control area compared with the soil samples from the experimental area was higher in each of the three seasons, but in contrast, the highest concentration of carbon in samples from the external control area was found in summer rather than in spring, and it was significantly higher $(\mathrm{p}=0.03)$ than that found in the experimental area (Fig. 2).

The highest concentration of total dissolved nitrogen (TDN) in soil samples from the external control area, similarly as in the case of the carbon, was found in summer and it was significantly higher $(p=0.03)$ than that found in the soil of the experimental area. In spring and autumn, the concentration of total dissolved nitrogen was at a similar level (Fig. 2). Activity of dehydrogenases (Dha) in soil samples from the external control area in the three seasons was lower than the ones in the experimental area, taking into account that differences were statistically insignificant (Fig. 2). No significant differences were also found between experimental area and external control area in acid phosphatase (APh) activity and microbial biomass (micC), in any of the seasons (Fig. 2).

On the experimental area no significant correlation between the tested parameters of soil biological activity was found, whereas on the external control area, a significant positive correlation was found between the activity of acid phosphatase and the concentration of total dissolved carbon, as well as the biomass of microorganisms and the concentration of total dissolved carbon and nitrogen in the soil (Table 3).

\section{Discussion}

In forest ecosystems, the soil is the element that determines the habitat's productivity as it influences the rate of growth and development of trees, as well as the structure and properties of wood (Jelonek et al. 2010; Tomczak and Jelonek 2013). As for indicators of direct activity, thus soil fertility, the enzyme, biomass and microbial activity, as 
TDC

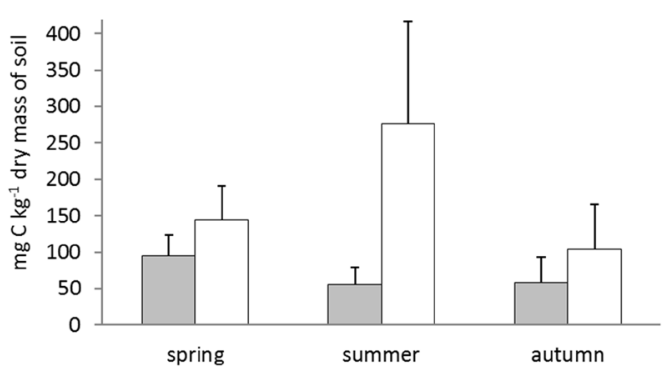

Dha

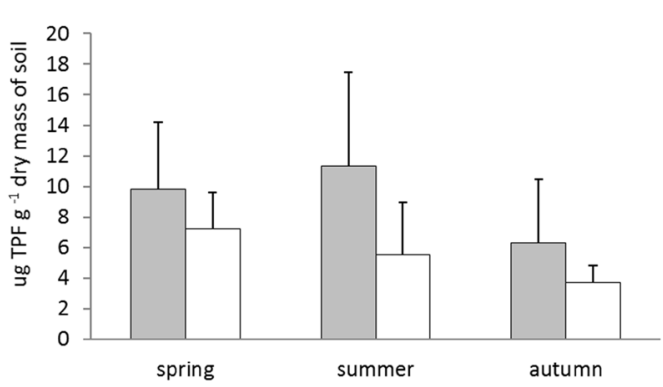

micC

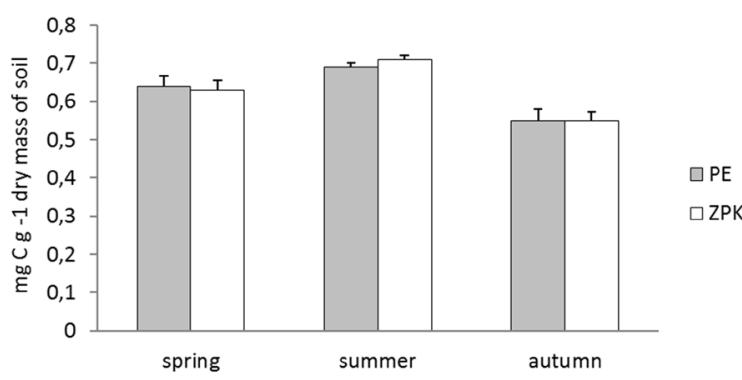

TDN

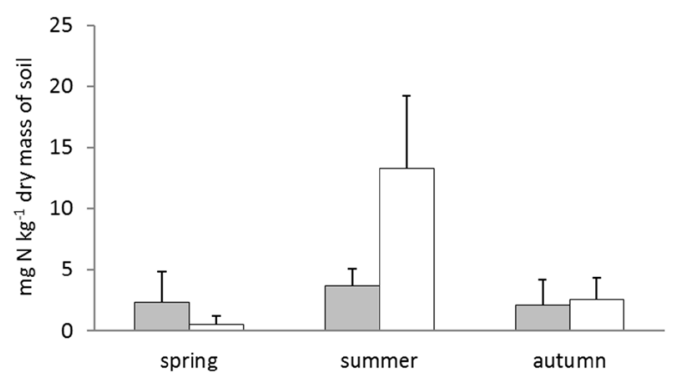

Aph

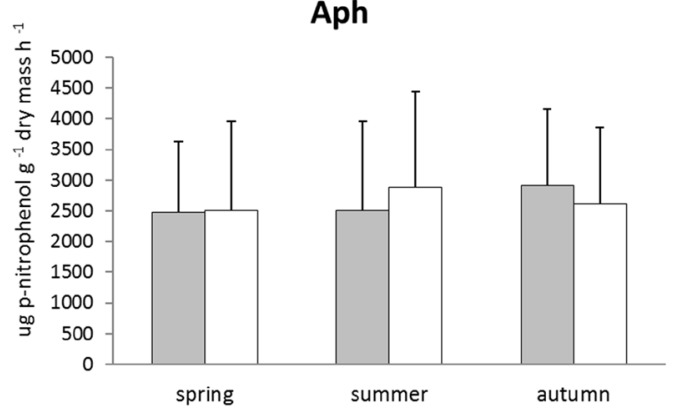

Fig. 2. Comparison of examined soil biological activity parameters on experimental area $(\mathrm{PE})$ and external control area (ZPK) in three seasons.

well as carbon and nitrogen content in the soil is measured (Nannipieri, Grego, and Ceccanti 1990; Kieliszewska-Rokicka 2001; Olszowska et al. 2005). Arable soil is fundamentally different from forest soil (Richards 1974; Tuszyński 1990), and a change of its use from typically agricultural into typical forest affects its physico-chemical and biological properties (Gorzelak1996; Kahle, Baum, and Boelcke 2005; Olszewska and Smal 2008; Smal and Olszewska 2008). However, according to some authors, even 30 years after afforestation, the soil is still, to a certain degree, more similar to arable soil than to forest soil, and forest stands on such soil are exposed to ad- verse pathogens and pests (Rykowski 1990; Smal and Olszewska 2008; Sierota 2013). Zwoliński (Zwoliński 1998) claims that the physio-chemical properties of soil change only after 30 years of use as forest type soil. Organic carbon compounds are then washed away into the soil mineral layer and topsoil is being formed. On the other hand, lower content of organic carbon and nitrogen in an afforested post-agricultural soil is the result of their high uptake from the soil during intensive tree growth in the first years after afforestation. This is also confirmed by more recent studies, which results were that the deeper the soil profile, the concentration of dissolved organic 
Table 3. The correlation between enzyme activity and biomass of microorganisms and concentration of total dissolved carbon and nitrogen in the soil of the experimental and external control area.

\begin{tabular}{ccccc}
\hline Area & Parameters & TDC & TDN & micC \\
\hline \multirow{2}{*}{ PE } & Dha & $0.264^{\text {n.s. }}$ & $0.313^{\text {n.s. }}$ & $0.335^{\text {n.s. }}$ \\
& APh & $0.250^{\text {n.s. }}$ & $0.261^{\text {n.s. }}$ & $0,037^{\text {n.s. }}$ \\
& micC & $0.172^{\text {n.s. }}$ & $0.251^{\text {n.s. }}$ & \\
\hline ZPK & Dha & $0.196^{\text {n.s. }}$ & $0.033^{\text {n.s. }}$ & $0.251^{\text {n.s. }}$ \\
& APh & $0.746^{* *}$ & $0.529^{\text {n.s. }}$ & $0,309^{\text {n.s. }}$ \\
& micC & $0.825^{\text {**.s. }}$ & $0.791^{\text {*.s. }}$ & \\
\hline
\end{tabular}

n.s. - correlation coefficient is not significant at $\mathrm{p}<0.05$; * - correlation coefficient is significant at $\mathrm{p}<0.05$

** - correlation coefficient is significant at $\mathrm{p}<0.025 ; * *$ - correlation coefficient is significant at $\mathrm{p}<0.01$

carbon and nitrogen decreases (Qualls et al. 2000; Rosenquist, Kleja, and Johansson 2010), but it also depends on the age of the forest stand. In older forest stands the concentration of dissolved organic matter, consisting of dissolved carbon and nitrogen, grows because its main source in the soil is the layer of accumulated plant litter (Justine et al. 2017).

These studies show that the total dissolved carbon content is more than 2.5 times higher and the total dissolved nitrogen content is more than 3.5 times higher in the soil of the external control area (forest soil) than in the afforested arable soil (in the control variant) (Table 2). Similar results were obtained by Bielińska and Hury (Bielińska and Hury 2009). They showed that natural forest soil on which grew 150 years old pine forest stand, contained about 2 times more organic carbon and about 1.5 times more total nitrogen than post-agricultural soil after $15-17$ years after afforestation with pine. Smal claimed that the afforestation of post-agricultural soil resulted in the increase of organic carbon, especially in topsoil comparing with adjacent soil of the farmland, and its content generally grew with the age of the forest stand (38, 54, and 70 years old) (Smal, Ligęza, and Olszewska 2004). It can also be confirmed by studies conducted by Vesterdal et al. (Vesterdal, Ritter, and Gunder- sen 2002) and Smal and Olszewska (2008) Moreover, in stands on post-agricultural soil, the decomposition and mineralization of accumulated plant litter are too slow as a result of excessive soil acidification or due to improperly shaped soil microflora and microfauna, which disturbs the biogeochemical cycle and disrupts the processes of accumulation of basic nutrients in the topsoil (Michalski, Sałek, and Płatek 2006; Chapin, Matson, and Vitousek 2012).

Numerous studies indicate that there is a close relationship between the soil enzyme activities and the content of organic carbon and the total nitrogen content (Andersson, Kjøller, and Struwe 2004; Domżał and Bielińska 2007; Bielińska and Hury 2009). Organic carbon content determines the development and activity of soil microflora, which is the main source of many soil enzymes (Kieliszewska-Rokicka 2001). In our research, in the soil of the experimental area, no significant correlation was found between the activity of dehydrogenases, acid phosphatase and biomass of microorganisms and the concentration of total dissolved carbon and nitrogen, and between the biomass of microorganisms and the activity of dehydrogenases and acid phosphatase. However, in the soil of the external control area a significant positive correlation between the activity of acid phosphatase and the concentration of total 
dissolved carbon and the biomass of microorganisms and the concentration of total dissolved carbon and nitrogen have been determined. Literature data show that the activity of dehydrogenases is closely related to soil $\mathrm{pH}$ and temperature (Wolińska and Stępniewska 2012). The external control area soil was characterized by a lower $\mathrm{pH}$ than the post-agricultural one, on experimental area (Tracz et al. 2014), which could have affected the reduced dehydrogenase activity, whereas the increased dehydrogenase activity in spring-summer, could be related to the increased temperature of the top layer of the soil and the increase in metabolic activity of microorganisms. In the presented studies, a significant increase in the content of carbon and nitrogen on the experimental area was achieved after the application of the variant of fertilization of the bark-sawdust-fauna. For this variant of fertilization, the increased activity of acid phosphatase was found, in comparison with the control variant, where no additional organic matter was added to the soil before afforestation and no additional soil fauna was introduced. Phosphatase catalyses the decomposition of organic phosphorus forms, which occur in the soil as an organic matter compound, especially with soluble organic carbon (Sapek 2014), and this is probably the cause of the increased activity of acid phosphatase in the variants, where the increased concentration of organic carbon was found.

The obtained results confirm previous studies, which indicated that bark and sawdust, as well as the introduction of soil fauna, improve soil properties, increase carbon and nitrogen content in the soil, and increase the activity of microorganisms. (Kwaśna and Sierota 1999; Kwaśna, Sierota, and Bateman 2000). Moreover, as indicated by the research of other authors, the change of soil use from agricultural to forest and enrichment of the soil by introducing sawdust leads to the reconstruction of the composition and structure of microorganisms towards the development and dominance of fungi over bacteria and changes in the abundance and diversity of soil fauna, mainly acari (Kwaśna, Sierota, and Bateman 2000; Hedlund 2002; van der Wall et al. 2006; Klimek and Rolbiecki 2011), which may be reflected in some physico-chemical and biological parameters of soil.

\section{Bibliography}

Anderson, John P. E., and Klaus H. Domsch. 1978. "A physiological method for the quantitative measurement of microbial biomass in soils." Soil Biology and Biochemistry 10: 215-221. https://doi.org/10.1016/00380717(78)90099-8.

Andersson, Michael, Annelise Kjøller, and Sten Struwe. 2004. "Microbial enzyme activities in leaf litter, humus and mineral soil layers in European forests." Soil Biology and Biochemistry 36: 1527-1537. https://doi.org/ 10.1016/j.soilbio.2004.07.018.

Bielińska, Elżbieta J., i Grzegorz Hury. 2009. "Zastosowanie testów enzymatycznych do oceny jakości gleb porolnych zalesionych sosną zwyczajną." W Tereny zdegradowane i rekultywowane - możliwości ich zagospodarowania, red. Sławomir Stankowski, Krzysztof Pacewicz, 7-15. Szczecin: P.P.H. Zapol Dmochowski Sp. j.

Casida, Lester E., Donald A. Klein., and Thomas Santoro. 1964. "Soil dehydrogenase activity." Soil Science 98: 371-376. https://doi. org/10.1097/00010694-196412000-00004.

Chapin III, Stuart F., Pamela A. Matson, and Peter M. Vitousek. 2012. Decomposition and ecosystem carbon budgets: principles of terrestrial ecosystems ecology. Second edition. New York: Springer-Verlag.

Domżał, Henryk, i Elżbieta J. Bielińska. 2007. "Ocena przeobrażeń środowiska glebowego i stabilności ekosystemów leśnych w obszarze oddziaływania Zakładów Azotowych „Puławy" S.A." Acta Agrophysica 145(2): 79-90.

Gorzelak, Andrzej. 1996. „Ekologiczne uwarunkowania kształtowania lasów na gruntach porolnych." Sylwan 140(5): 29-41.

Hedlund, Katarina. 2002. "Soil microbial community structure in relation to vegetation management on former agricultural land." Soil Biology and Biochemistry 34:1299-1307. https://doi.org/10.1016/S0038-0717(02)00073-1. Jelonek, Tomasz, Witold Pazdrowski, Magdalena Arasimowicz-Jelonek, i Arkadiusz Tomczak. 
2010. „Właściwości drewna sosny zwyczajnej (Pinus sylvestris L.) pochodzącej z gruntów porolnych." Sylwan 154(5): 299-311.

Justine, Meta F., Wanqin Yang, Fuzhong Wu, Bo Tan, Muhammad N Khan, and Zhijie Li. 2017. "Dissolved organic matter in soils varies across a chronosequence of Pinus massoniana plantations." Ecosphere 8(4): e01764. https://doi.org/10.1002/ecs2.1764.

Kahle, Petra, Christel Baum, and Barbara Boelcke. 2005. "Effect of afforestation on soil properties and mycorrhizal formation." $\mathrm{Pe}$ dosphere 15(6): 754-760.

Kaliszewski, Adam, Emilia Wysocka-Fijorek, Marek Jabłoński, i Wojciech Młynarski. 2014. Aktualizacja krajowego programu zwiększania lesistości 2014. Synteza. Dokumentacja IBL, Warszawa. Dostęp 16.10.2020. https://docplayer.pl/1593283-Aktualizacja-krajowego-programu-zwiekszania-lesistosci-2014-synteza.html.

Kieliszewska-Rokicka, Barbara. 2001. „Enzymy glebowe i ich znaczenie w badaniach aktywności mikrobiologicznej gleby." W Drobnoustroje środowiska glebowego, aspekty fizjologiczne, biochemiczne, genetyczne, red. Hanna Dahm, i Aleksandra Pokojska-Burdziej, 3747. Toruń: Wydawnictwo Adam Marszałek.

Klimek, Andrzej, i Stanisław Rolbiecki, 2011. „Wzrost sosny zwyczajnej (Pinus sylvestris L.) i występowanie roztoczy (Acari) glebowych na rekultywowanym terenie popoligonowym w nadleśnictwie Żołędowo." Infrastruktura i Ekologia Terenów Leśnych 1: 249-262.

Krawczyk, Robert. 2014. „Zalesienia a sukcesja wtórna." Leśne Prace Badawcze 75(4): 423-427.

Kwaśna, Hanna, and Sierota, Zbigniew. 1999. "Structure of fungal communities in barren post agricultural soil 1-and 2-years after pine sawdust application." Phytopathologia Polonica 17: 13-21.

Kwaśna, Hanna, Zbigniew Sierota, and Geoffrey L. Bateman. 2000. "Fungal communities in fallow soil before and after amending with pine sawdust." Applied Soil Ecology 14: 177-182. https://doi.org/10.1016/S0929-1393(00)00044-5.

Michalski, Artur, Paweł Sałek, i Krzysztof Płatek. 2006. „Zależność grubości ściółki od wieku drzewostanów sosnowych rosnących na glebach porolnych i leśnych." Syl- wan 8: 20-25. https://doi.org/10.26202/sylwan.2006056.

Nannipieri, Paolo, Stefano Grego, and Brunello Ceccanti. 1990. "Ecological significance of the biological activity in soil." In Soil Biochemistry, vol. 6, edited by Jean-Marc Bollag, and Guenther Stotzky, 293-355. New York: Marcell Dekker.

Olszewska, Marta, and Halina Smal. 2008. "The effect of afforestation with Scots pine (Pinus sylvestris L.) of sandy post-arable soils on their selected properties. I. Physical and sorptive properties." Plant Soil 30: 157-169.

Olszowska, Grażyna, Józef Zwoliński, Irena Matuszczyk, Danuta Syrek, Barbara Zwolińska, Urszula Pawlak, Zygmunt Kwapis, i Małgorzata Dudzińska. 2005. „Wykorzystanie badań aktywności biologicznej do wyznaczenia wskaźnika żyzności gleb w drzewostanach sosnowych na siedliskach boru świeżego i boru mieszanego świeżego." Leśne Prace Badawcze 3: 17-37.

Oszako, Tomasz, i Ireneusz Olejarski. 2003. „Inicjowanie procesów przekształcania gleb porolnych w gleby leśne poprzez wykorzystanie pozostałości zrębowych, kompostów i trocin." Prace IBL, Ser. A 1: 76-79.

Qualls, Robert G., Bruce L. Haines, Wayne T. Swank, and Scott W. Tyler. 2000. "Soluble organic and inorganic nutrient fluxes in clearcut and mature deciduous forests." Soil Science Society of America Journal 64: 1068-1077. https://doi.org/10.2136/sssaj2000.6431068x.

Richards, Bryant N. 1974. Introduction to the soil ecosystem. London: Longman Group Ltd. Rosenquist, Lars, Dan B. Kleja, and Maj-Britt Johansson. 2010. "Concentrations and fluxes of dissolved organic carbon and nitrogen in a Picea abies chronosequence on former arable land in Sweden." Forest Ecology and Management 259(3): 275-285. https://doi. org/10.1016/j.foreco.2009.10.013.

Rykowski, Kazimierz. 1990. "Problemy ochrony lasu na gruntach porolnych/Problems of forest protection on afforested agricultural grounds." Sylwan 134(3-12): 75-88.

Sapek, Barbara. 2014. „Nagromadzanie i uwalnianie fosforu w glebach - źródła, procesy, przyczyny." Woda-Środowisko-Obszary Wiejskie 14: 77-100.

Sierota, Zbigniew. 2013. "Heterobasidion root rot in forests on former agricultural lands in 
Poland: Scale of threat and prevention." Scientific Research and Essays 8(47): 2298-2305. https://doi.org/10.5897/SRE2013.5724.

Sierota, Zbigniew, Mieczysław Błaszczyk, i Tadeusz Zachara. 2011. „Wpływ przebudowy drzewostanu na gruncie porolnym na wybrane elementy środowiska leśnego." W Zmiany w środowisku drzewostanów sosnowych na gruntach porolnych $w$ warunkach przebudowy częściowej oraz obecności grzyba Phlebiopsis gigantea. red. Zbigniew Sierota, 251-272. Sękocin Stary: Instytut Badawczy Leśnictwa.

Smal, Halina, Sławomir Ligęza, i Marta Olszewska. 2004. „Wpływ zalesienia piaszczystych gleb porolnych na jakość materii organicznej i skład chemiczny roztworu glebowego." Roczniki Gleboznawcze 55(4): 139-148.

Smal, Halina, and Marta Olszewska. 2008. "The effect of afforestation with Scots pine (Pinus silvestris L.) of sandy post-arable soils on their selected properties. II. Reaction, carbon, nitrogen and phosphorus." Plant Soil 305: 171-187. https://doi.org/10.1007/s11104-008-9538-z.

Sobczak, Rafał. 1990. „Teoretyczne i praktyczne aspekty zakładania upraw i prowadzenia drzewostanów na gruntach porolnych." Sylwan 134(3-12): 61-74.

Sobczak, Rafał. 1996. „Przywracaniu lasów na grunty porolne w Polsce." Sylwan 140(5): 35-41.

Szujecki, Andrzej. 1990. „Ekologiczne aspekty odtwarzania ekosystemów leśnych na gruntach porolnych." Sylwan 134(3-12): 23-40.

Tabatabai, M. Ali, and John M. Bremner. 1969. "Use of p-nitrophenol phosphate for assay of soil phosphatase activity." Soil Biology and Biochemistry 1: 301-307.

Tomczak, Arkadiusz, i Tomasz Jelonek. 2013. „Promieniowa zmienność właściwości drewna sosny zwyczajnej (Pinus sylvestris L.) wyrosłej na gruntach porolnych." Leśne Prace Badawcze 74(2): 171-177.

Tracz, Henryk. 1984. "Studies on the ecology of Proteroiulus fuscus (Am Stein 1857) (Diplopoda, Blaniulidae)." Acta Zoologica Cracoviensia 27(2): 519-576.
Tracz, Henryk, Marta Aleksandrowicz-Trzcińska, Anna Augustyniuk-Kram, Bogdan Brzeziecki, Stanisław Drozdowski, Karol Kram, Sławomir Mazur, Jacek Piętka, Małgorzata Sławska, Marek Sławski, Andrzej Szujecki, i Taida Tarabuła. 2014. Ekosystem leśny na gruntach porolnych - ocena skuteczności wybranych zabiegów rekultywacyjnych po 30 latach od ich zastosowania w borach sosnowych Polski ptn-zach (sprawozdanie końcowe). Dostęp 29. 04. 2018. http://www.lasy.gov.pl/pl/ pro/publikacje/copy_of_gospodarka-lesna/ ochrona_lasu/201eekosystem-lesny-na-gruntach-porolnych-2013-ocena-skutecznosci-wybranych-zabiegow-rekultywacyjnych-po-30-latach-od-ich-zastosowania-w-borach-sosnowych-polski-pn-zach201d.

Tuszyński, Mieczysław. 1990. „Właściwości gleb porolnych a gospodarka leśna." Sylwan 134(3-12): 41-50.

Wolińska, Agnieszka, and Zofia Stępniewska. 2012. "Dehydogenase Activity in Soil Ecosystem." In Dehydrogenases, edited by Rosa Angela Canuto, 183-210. Rijeka: Intech. https://doi.org/10.5772/48294.

van der Wal, Annemieke, Johannes A. van Veen, Wiecher Smant, Henricus T. S. Boschker, Jaap Bloem, Paul Kardol, Wim H. van der Putten, and Wietse de Boer. 2006. "Fungal biomass development in a chronosequence of land abandonment." Soil Biology and Biochemistry 38: 51-60. https://doi.org/10.1016/j.soilbio.2005.04.017.

Vesterdal, Lars, Eva Ritter, and Per Gundersen. 2002. "Change in soil organic carbon following afforestation of former arable land." Forest Ecological Management 169: 137-147. Zajączkowski, Grzegorz, Marek Jabłoński, Tomasz Jabłoński, Monika Małecka, Anna Kowalska, Jadwiga Małachowska, i Józef Piwnicki. 2017. Raport o stanie lasów $w$ Polsce 2016. Dostęp 29. 04. 2018. https://www.lasy.gov.pl/pl/informacje/publikacje/informacje-statystyczne-i-raporty/raport-o-stanie-lasow/raport_2016. pdf/@@download/file/Raport_2016.pdf.

Zwoliński, Józef. 1998. „Obieg węgla w borach sosnowych." Prace IBL Ser. A, 862: 141-155. 